\title{
Evaluation of mean platelet volume and platelet count in patients with hidradenitis suppurativa
}

\author{
Hidradenitis süpürativada ortalama trombosit hacmi ve trombosit sayısının \\ değerlendirilmesi
}

๑ Alkım Ünal

Medipol University Faculty of Medicine, Department of Dermatology, İstanbul, Turkey

\begin{abstract}
Background and Design: Hidradenitis suppurativa (HS) is a chronic inflammatory condition of the apocrine glands. The mean platelet volume (MPV) is a risk factor for many inflammatory diseases and can be used as a marker of inflammatory response. This study aimed to evaluate the MPV and platelet count in patients with HS and compare them with those of healthy controls.

Materials and Methods: Between September 2014 and October 2019, 97 patients diagnosed with HS and 78 healthy controls were included. Their MPVs and platelet counts were compared retrospectively.

Results: The MPV was $10.17 \pm 0.94$ in the patient group and $9.53 \pm 0.63$ in the control group, with the difference being significant $(p<0.05)$. No significant difference was noted between the groups in terms of platelet values.

Conclusion: The MPV was significantly higher in patients with HS than in healthy controls. Based on this finding, the MPV may be used as an inflammatory marker in this patient group.

Keywords: Hidradenitis suppurativa, mean platelet volume, inflammatory markers, platelet parameters, systemic inflammation

Öz

Amaç: Hidradenitis süpürativa (HS), apokrin bezlerin kronik, inflamatuvar bir deri hastalı̆ıdır. Ortalama trombosit hacminin (MPV) birçok inflamatuvar hastalık için risk faktörü olduğu ve inflamatuvar yanıtın belirteci olarak kullanılabileceği gösterilmiştir. Bu çalışmanın amacı, HS tanılı hastalarda MPV ve trombosit sayısı parametrelerini değerlendirmek ve sağlıklı kontrollerle karşılaştırmaktır.

Gereç ve Yöntem: Eylül 2014 ve Ekim 2019 tarihleri arasında kliniğimizde izlenen 97 HS tanılı hasta ile 78 sağlıklı kontrol grubu çalışmaya dahil edildi. Hastaların MPV ve trombosit sayısı parametreleri retrospektif olarak karşılaştıııldı.

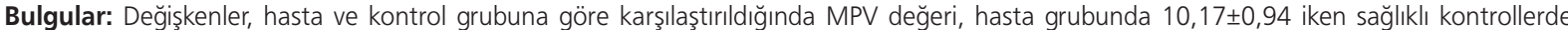
$9,53 \pm 0,63$ olarak saptandı. iki grup arasında anlamlı fark bulundu $(p<0,05)$. Trombosit değerleri arasında anlamlı fark saptanmadı.

Sonuç: MPV düzeyleri HS tanılı hastalarda sağlıklı kontrol grubuna göre anlamlı düzeyde yüksekti. Buna dayanarak MPV değerinin bu hasta grubunda da bir inflamatuvar belirteç olarak kullanılabilir olduğunu düşünüyoruz.

Anahtar Kelimeler: Hidradenitis süpürativa, ortalama trombosit hacmi, inflamatuvar belirteçler, trombosit parametreleri, sistemik inflamasyon
\end{abstract}

Address for Correspondence/Yazışma Adresi: Alkım Ünal MD, Medipol University Faculty of Medicine, Department of Dermatology, İstanbul, Turkey Phone: +90 5335565980 E-mail: alkimuna|@hotmail.com Received/Geliș Tarihi: 25.02.2021 Accepted/Kabul Tarihi: 19.05.2021 ORCID: orcid.org/0000-0002-4119-9939

Cite this article as: Ünal A. Evaluation of mean platelet volume and platelet count in patients with hidradenitis suppurativa. Turkderm-Turk Arch Dermatol Venereol 2021:55:189-92 


\section{Introduction}

Hidradenitis suppurativa (HS) is a chronic inflammatory skin disease of the apocrine glands and is characterized by nodules, abscesses, sinus tracts, and scars. The primary mechanism underlying HS is the follicular occlusion of the folliculosebaceous unit, followed by follicular rupture and the resulting immune response ${ }^{1}$. Platelets play an important role in inflammation and inflammatory diseases ${ }^{2}$. Mean platelet volume (MPV) is considered as a marker of platelet function and activation ${ }^{3,4}$. Reportedly, a high MPV is a risk factor for certain inflammatory diseases, such as ankylosing spondylitis and rheumatoid arthritis ${ }^{5}$. In recent years, several studies have been conducted to evaluate the relationship between MPV and platelet counts in various dermatological diseases, including psoriasis ${ }^{6}$, chronic spontaneous urticaria $^{7}$, localized scleroderma ${ }^{8}$, pemphigus vulgaris ${ }^{9}$, and rosacea ${ }^{10}$; these studies have reported different results. However, there are only few studies investigating the role of MPV and platelet count in $\mathrm{HS}^{11,12}$. In this study, I compared MPV and platelet counts of patients with HS with those of healthy controls. By examining the relationship of these values with disease severity and the number of involvement areas, I aimed to determine the utility of these parameters as markers in HS follow-up.

\section{Materials and Methods}

This study was approved by the Ethics Committee of Medipol University Faculty of Medicine (approval number: 939, date: 6.11.2019). All patients who presented to our clinic between September 2014 and October 2019 and were diagnosed with HS were retrospectively reviewed. In total, 97 patients with satisfying the following inclusion criteria were included: diagnosed with HS by a dermatologist, had complete blood count analysis results during follow-up, did not have any systemic and/or chronic inflammatory diseases (e.g., cardiac diseases, diabetes mellitus, hypertension, hyperlipidemia, and rheumatoid arthritis), and did not smoke. Patients with missing data were excluded from the study. The control group comprised 78 age- and sex-matched healthy volunteers with no known systemic and/or inflammatory diseases, who did not smoke, had no acne vulgaris or chronic dermatological disease, and did not take regular medications. For both patient and control groups, the following data were retrospectively obtained from hospital records: demographic characteristics; hemoglobin; hematocrit; mean corpuscular hemoglobin $(\mathrm{MCH}) ; \mathrm{MCH}$ concentration $(\mathrm{MCHC})$; red blood cell distribution width (RDW); white blood cell (WBC) count; and hematologic parameters including neutrophils, lymphocytes, platelets, and MPV. In addition, the number of involvement areas and Hurley stages of the patient group were obtained. Demographic characteristics of the patient group are shown in Table 1.

\section{Statistical Analysis}

Data were statistically analyzed using the Kolmogorov-Smirnov normality test, t-test, Mann-Whitney $U$ test, Spearman's correlation test, and receiver operating characteristic (ROC) curve analysis with the Youden index. Data analysis was performed using the Statistical Package for the Social Sciences (IBM SPSS Statistics v. 25.0). Results with a p-value of $<0.05$ were considered statistically significant.

\section{Results}

Of the 213 patients diagnosed with HS who were retrospectively screened, 97 were eligible for inclusion in the study. The patient group comprised 48 females and 49 males, with a mean age of 33.4 years. The age and sex distribution of healthy volunteers was similar to that of the patients. Hurley severity was 2 or more in $89 \%$ of patients (Hurley I: 11 patients, Hurley II: 76 patients, and Hurley III: 10 patients). In the patient group, areas of involvement were axillary, inguinal, intergluteal, inframammary, gluteal, and cervical in 67\%, 64\%, 10.3\%, 10.3\%, $8.2 \%$, and $4.1 \%$ patients, respectively. The mean hemogram values of the patient and control groups are shown in Table 2. The patient and control groups differed significantly with regard to MPV, WBC, MCHC, neutrophil count, lymphocyte count, and RDW ( $p<0.05)$. The MPV, WBC, lymphocyte count, and RDW were significantly higher in the patient group, whereas the MCHC and neutrophil counts were significantly higher in the control group. Assessment of the relationship of Hurley severity and the number of areas involved with MPV and platelet counts in the patient group revealed that Hurley severity was not associated with platelet counts $(p>0.05)$. There was an inverse but very weak correlation between the number of involved areas and MPV ( $r=-0.23 ; p<0.05)$ (Table 3). When MPVs of the two groups were compared using ROC analysis to determine the threshold that could be considered as the inflammatory marker level, the cut-off value was determined as 10.05 , at which MPV had $49.5 \%$ sensitivity and $82.1 \%$ specificity in discriminating between the two groups. When this cutoff value was used to classify patients and a cross-table with real data was constructed, $43.4 \%$ of data classified as belonging to the controls were actually obtained from patients and $77.4 \%$ of data classified as belonging to patients actually belonged to the patients. According

\begin{tabular}{|c|c|}
\hline & n (\%) \\
\hline \multicolumn{2}{|l|}{ Sex } \\
\hline Female & $48(49.4 \%)$ \\
\hline Male & $49(50.6 \%)$ \\
\hline \multicolumn{2}{|l|}{ Hurley stage } \\
\hline 1 & $11(11.3 \%)$ \\
\hline 2 & $76(78.4 \%)$ \\
\hline 3 & $10(10.3 \%)$ \\
\hline \multicolumn{2}{|l|}{ Smoking status } \\
\hline Non-smoker & $97(100 \%)$ \\
\hline Smoker & $0(0 \%)$ \\
\hline \multicolumn{2}{|c|}{ Systemic disease } \\
\hline None & $97(100.0 \%)$ \\
\hline \multicolumn{2}{|c|}{ Area of involvement } \\
\hline Axillary & $65(67.0 \%)$ \\
\hline Inguinal & $62(63.9 \%)$ \\
\hline Intergluteal & $10(10.3 \%)$ \\
\hline Inframammary & $10(10.3 \%)$ \\
\hline Gluteal & $8(8.2 \%)$ \\
\hline Cervical & $4(4.1 \%)$ \\
\hline
\end{tabular}




\begin{tabular}{|c|c|c|c|c|}
\hline & Patient & Control & Total & $\mathbf{p}$ \\
\hline Mean platelet volume & $10.17 \pm 0.94$ & $9.53 \pm 0.63$ & $9.88 \pm 0.88$ & $0.000^{*}$ \\
\hline White blood cell count & $9.60 \pm 2.78$ & $7.65 \pm 2.26$ & $8.73 \pm 2.73$ & $0.000^{*}$ \\
\hline Red blood cell count & $4.96 \pm 0.72$ & $4.96 \pm 0.84$ & $4.96 \pm 0.77$ & 0.438 \\
\hline Hematocrit level & $40.73 \pm 4.38$ & $39.91 \pm 5.16$ & $40.36 \pm 4.74$ & 0.256 \\
\hline Mean corpuscular hemoglobin & $28.14 \pm 2.09$ & $32.68 \pm 29.58$ & $30.17 \pm 19.87$ & 0.067 \\
\hline Mean corpuscular hemoglobin concentration & $33.84 \pm 1.52$ & $34.39 \pm 1.68$ & $34.09 \pm 1.61$ & $0.003^{*}$ \\
\hline Neutrophil count & $5.93 \pm 2.37$ & $8.31 \pm 34.77$ & $6.99 \pm 23.22$ & $0.000^{*}$ \\
\hline Lymphocyte count & $2.66 \pm 0.89$ & $2.40 \pm 0.88$ & $2.55 \pm 0.89$ & $0.006^{*}$ \\
\hline
\end{tabular}

to the result of Fisher's exact test in chi-square analysis, a significant association was found between ROC classification and the real groups $(p<0.05)$ (Table 4).

\section{Discussion}

HS is a chronic, recurrent inflammatory skin disease of the apocrine glands involving the axillary, inguinal, and anogenital regions and is characterized by painful nodules, abscesses, sinus tracts, and scars ${ }^{1}$. It presents as chronic inflammatory dermatosis that can accompany various diseases and conditions, such as obesity, systemic amyloidosis, spondyloarthropathies, and Crohn's disease ${ }^{13-15}$. Reportedly, the link between MPV and inflammation has been evaluated in many inflammatory and dermatological diseases, with no consensus in the results. Increased MPV may be a risk factor for certain inflammatory diseases, including ankylosing spondylitis and rheumatoid arthritis, and can be used as a marker for these diseases ${ }^{5}$.

Altunisik et al. ${ }^{10}$ compared MPVs and RDWs of 90 patients with acne rosacea and 62 controls and found no significant difference between the groups. Similarly, a retrospective study conducted by islamoğlu and Demirbaş ${ }^{16}$ compared 105 patients with alopecia areata and 108 healthy controls in terms of MPV, RDW, neutrophil/lymphocyte ratio, and platelet/lymphocyte ratio; the study found no significant differences between the two groups. In contrast, in their follow-up of 70 patients with acne vulgaris initiated on systemic isotretinoin treatment, Tamer et al. ${ }^{17}$ found that MPVs had significantly decreased by the third month of treatment. Thus, they suggested that MPV could be used as an inflammatory marker. Likewise, Ertaş et al. ${ }^{7}$ evaluated patients with chronic spontaneous urticaria and reported higher MPVs than in healthy controls. They also attributed the increase in MPVs among patients during omalizumab treatment to platelet activation. Another case-control study conducted by Ataş et al. ${ }^{18}$ recruited 100 patients with Behçet's disease and 100 healthy controls. The study revealed that MPV in the patient group was significantly higher and the platelet count was lower. The authors suggested that a high MPV might be considered as a risk factor for thrombosis. Similarly, in a casecontrol study including patients with Behçet's disease conducted by Balta et al. ${ }^{19}$, MPVs and arterial stiffness measurements (accepted
Table 3. Correlation of the Hurley score and the number of involved areas with MPV in the patient group [Spearman's correlation test, $\mathbf{r}(\mathrm{p})]$

\begin{tabular}{|l|l|l|}
\hline & MPV & PLT \\
\hline Hurley score & $-0.20(0.051)$ & $0.07(0.521)$ \\
\hline Number of involved areas & $-0.23(0.023)^{*}$ & $0.13(0.198)$ \\
\hline MPV & - & $-0.39(0.001)^{*}$ \\
\hline
\end{tabular}

"Significant at the level of 0.05, MPV: Mean platelet volume, PLT: Trombosit

Table 4. Cross-table of groups using the ROC classification (chisquare analysis)

\begin{tabular}{|l|l|l|l|l|}
\hline ROC class/original & Control & Patient & Total & p \\
\cline { 1 - 4 } Control & $64(56.6)$ & $49(43.4)$ & $113(100.0)$ & \\
\cline { 1 - 4 } Patient & $14(22.6)$ & $48(77.4)$ & $62(100.0)$ & \multirow{2}{*}{$0.000^{*}$} \\
\cline { 1 - 4 } Total & $78(44.6)$ & $97(55.4)$ & $175(100.0)$ & \\
\cline { 1 - 3 } & & &
\end{tabular}

*Statistically significant at 0.05, ROC: Receiver operating characteristic

marker of subclinical atherosclerosis) were compared between the patient and control groups. The authors found that increased MPVs were associated with arterial stiffness in patients with Behçet's disease without significant cardiovascular involvement. In another study, Ekiz et al. ${ }^{20}$ compared MPVs in patients with Behçet's disease, those with recurrent aphthous stomatitis (RAS), and healthy participants. They determined that MPVs and erythrocyte sedimentation rates of the Behçet's disease and RAS groups were significantly higher than those of the control group. Similarly, Bahali et al. ${ }^{8}$ compared MPVs and platelet counts of patients with localized scleroderma, a chronic inflammatory skin disease, with those of healthy controls. They found that MPVs were significantly higher in the patient group; however, no significant difference was found in the platelet count.

There are also studies investigating MPVs in patients with psoriasis vulgaris and exploring the relationship between MPV and psoriasis area severity index (PASI) in this patient group. For example, Kılıç et al. ${ }^{21}$ compared the MPV of patients with psoriasis vulgaris, psoriatic arthritis, and healthy controls. They found that MPV was significantly higher in the psoriasis vulgaris and psoriatic arthritis groups, which was attributed 
to psoriasis being a chronic inflammatory disease. The authors noted the presence of a weak statistical correlation between MPV and PASI. Kim et al. ${ }^{22}$ reported similar results in 176 patients with psoriasis. In contrast, Kridin et al. ${ }^{9}$, who compared the MPV of 160 patients with pemphigus vulgaris and 640 controls, reported significantly lower MPVs in the patient group.

From the literature, we identified two studies that investigated MPV and platelet count in patients with HS. The first is by Yaşar et al. ${ }^{12}$, who evaluated 35 patients with HS but did not include a control group. The authors determined the stage of patients based on the severity of the disease according to the Hurley classification and divided patients into three groups. They compared hematological parameters between these three groups but did not find a significant difference in MPVs. In the second study, Miller et al. ${ }^{11}$ investigated the prothrombotic/ hypercoagulative status among patients with HS. They assessed 32 patients with HS in the hospital, with 430 patients with a populationbased HS diagnosis, and 780 controls without HS. Comparison of MPV, international normalized ratio, and activated partial thromboplastin time revealed no significant differences between the three groups. In this study, we compared 97 patients with HS who presented to our clinic and were diagnosed by a dermatologist and 78 healthy controls. Unlike the two literature studies mentioned above, I found that MPV was significantly higher in the patient group. In addition, WBC, lymphocyte counts, and RDW were significantly higher in the patient group, while the MCHC and neutrophil counts were significantly higher in the control group. In contrast to the study by Yaşar et al. ${ }^{12}$, I found no relationship between Hurley severity and MPV in patients with HS. In my study, MPVs in the patient and control groups were $10.17 \pm 0.94$ and $9.53 \pm 0.63$, respectively. A comprehensive cohort study by Demirin et al. ${ }^{23}$ reported that MPV varies between 7.2 and $11.7 \mathrm{fL}$ in healthy individuals. Thus, MPVs of the patient and control groups in my study and the value of 10.05 detected as an inflammatory marker were within the normal range reported by Demirin et al. ${ }^{23}$

\section{Study Limitations}

The following can be considered as the limitations of my study: Retrospective design, MPVs of few patients were measured while they were receiving anti-inflammatory treatment despite the controls not receiving any such treatment, and the limited number of patients and controls. These may have affected my results.

\section{Conclusion}

We noted a significantly higher MPV in patients with HS than in controls. The high MPVs in many chronic inflammatory diseases, reported in previous studies, confirms the findings of our study. However, there is a need for prospective studies, with a greater number of patients, to determine whether MPV can be used as an inflammatory or a prognostic marker in patients with HS. In addition, prospective studies comparing long-term follow-up data will allow for the evaluation of changes in the level of inflammatory markers throughout the disease course.

\section{Ethics}

Ethics Committee Approval: This study was approved by the Ethics Committee of Medipol University Faculty of Medicine (approval number: 939, date: 6.11.2019).

Informed Consent: Retrospective study.

Peer-review: Externally peer-reviewed.
Financial Disclosure: The author declared that this study received no financial support.

\section{References}

1. Wiseman MC: Hidradenitis suppurativa: A review. Dermatol Ther 2004;17:50-4.

2. von Hundelshausen $P$, Weber C: Platelets as immune cells bridging inflammation and cardiovascular disease. Circ Res 2007;100:27-40.

3. Park Y, Schoene N, Harris W: Mean platelet volume as an indicator of platelet activation: methodological issues. Platelets 2002;13:301-6.

4. Mahdavi-Zafarghandi R, Shakiba B, Keramati MR, Tavakkoli M: Platelet volume indices in patients with varicocele. Clin Exp Reprod Med 2014;41:92 5.

5. Kisacik B, Tufan A, Kalyoncu $U$, et al.: Mean platelet volume as an inflammatory marker in ankylosing spondylitis and rheumatoid arthritis. Joint Bone Spine 2008;75:291-4.

6. Korkmaz S: Mean platelet volume and platelet distribution width levels in patients with mild psoriasis vulgaris with metabolic syndrome. Postepy Dermatol Alergol 2018;35:367-71.

7. Ertaş R, Özyurt K, Karakükçü Ç, et al.: Evaluation of platelet parameters and neutrophil/lymphocyte ratio during omalizumab treatment in patients with severe chronic spontaneous urticaria. Turk J Med Sci 2018;48:1255-62.

8. Bahali AG, Su O, Emiroglu N, Cengiz FP, Kaya MO, Onsun N: Evaluation of mean platelet volume in localized scleroderma. An Bras Dermatol 2017:92:635-7.

9. Kridin K, Shihade $\mathrm{W}$, Zelber-Sagi S: Mean platelet volume in pemphigus vulgaris. Angiology 2018;69:303-7.

10. Altunisik N, Turkmen D, Sener S: Investigation of the relationship between inflammatory blood parameters and rosacea and demodex infestation. J Cosmet Dermatol 2020;19:2105-8.

11. Miller IM, Johansen ME, Mogensen UB, Zarchi K, Ellervik C, Jemec GB: Coagulation status in hidradenitis suppurativa: A Danish population- and hospital-based cross-sectional study. Dermatology 2015;231:119-26.

12. Yaşar NF, Uylas MU, Baspinar M, et al.: Evaluating the use of hematological parameters in staging hidradenitis suppurativa. Wounds 2016;28:87-91.

13. Jansen I, Altmeyer P, Piewig G: Acne inversa (alias hidradenitis suppurativa). J Eur Acad Dermatol Venereol 2001;15:532-40.

14. Fimmel S, Zouboulis CC: Comorbidities of hidradenitis suppurativa (acne inversa). Dermatoendocrinol 2010;2:9-16.

15. Lee RA, Yoon A, Kist J: Hidradenitis suppurativa: An update. Adv Dermatol 2007;23:289-306.

16. İslamoğlu ZGK, Demirbaş A: Evaluation of complete blood cell and inflammatory parameters in patients with alopecia areata: Their association with disease severity. J Cosmet Dermatol 2020;19:1239-45.

17. Tamer F, Yuksel ME, Avcl E: Is mean platelet volume an inflammatory marker in acne patients treated with isotretinoin? Acta Dermatovenerol Alp Pannonica Adriat 2019;28:65-9.

18. Ataş H, Canpolat F, Eskioglu F: Evaluation of mean platelet volume in patients with Behcet's disease as an indicator of vascular thrombosis. Arch Iran Med 2018;21:234-9.

19. Balta I, Balta S, Koryurek OM, et al.: Mean platelet volume is associated with aortic arterial stiffness in patients with Behçet's disease without significant cardiovascular involvement. J Eur Acad Dermatol Venereol 2014;28:138893.

20. Ekiz O, Balta I, Sen BB, et al:: Mean platelet volume in recurrent aphthous stomatitis and Behçet disease. Angiology 2014;65:161-5.

21. Kııç S, Reşorlu H, Işik $S$, et al.: Association between mean platelet volume and disease severity in patients with psoriasis and psoriatic arthritis. Postepy Dermatol Alergol 2017;34:126-30.

22. Kim DS, Lee J, Kim SH, Kim SM, Lee MG: Mean platelet volume is elevated in patients with psoriasis vulgaris. Yonsei Med J 2015;56:712-8.

23. Demirin $\mathrm{H}$, Ozhan $\mathrm{H}$, Ucgun $\mathrm{T}$, et al.: Normal range of mean platelet volume in healthy subjects:Insight from a large epidemiologic study. Thrombs Res 2011;128:358-60. 